\title{
CLIMATE FINANCE IN THE ASIA-PACIFIC REGION: TRENDS AND INNOVATIVE APPROACHES
}

\author{
Ilaria Carrozza*
}

\begin{abstract}
Asia and the Pacific ${ }^{1}$ is one of the most disaster-prone regions and the possibility that climate change may exacerbate the frequency and severity of extreme weather events is a real threat to progress made towards achieving sustainable development. To secure sustainable development gains and build resilience in the region, there is an urgent need to undertake climate mitigation and adaptation action. Despite an estimated $\$ 391$ billion in climate finance flows internationally in 2014, the gap between available climate finance and the financing required to limit global warming to two degrees Celsius and adapt to unavoidable impacts of climate change is growing. The present paper offers an overview of the climate finance landscape with a focus on the Asia-Pacific region, and of finance flows from international climate funds, multilateral development banks and subregional and national climate finance initiatives. The ultimate goal of the discussion is to provide policymakers in the region with an understanding of the state of climate finance and recommendations on approaches for mobilizing climate finance in the light of global efforts, regional trends and successful initiatives.
\end{abstract}

JEL classification: F39, Q01, Q54, Q56, R11.

Keywords: Asia-Pacific, climate change, climate finance, mitigation, adaptation.

Ilaria Carrozza, PhD candidate in International Relations, The London School of Economics and Political Science (LSE), United Kingdom. The author would like to acknowledge the ESCAP Environment and Development Division (Rae Kwon Chung, Aneta Nikolova, Riccardo Mesiano, Hala Razian, and with support from Yohan Hong). A peer review was conducted by the Climate Policy Initiative (Mia Fitri and Leela Raina).

This article considers the 62 member and associate members of ESCAP as far as data are available. See www.unescap.org/about/member-states. 


\section{INTRODUCTION}

While climate change is a global phenomenon, some geographic regions are being affected by it to a greater extent than others. Asia and the Pacific is one such region. It is home to the largest number of poor people in the world who are also the most vulnerable to the impacts of climate change. In the past decade, about three million people were affected by disasters and almost 900,000 lost their lives. A person living in Asia and the Pacific is almost twice as likely to be affected by a natural disaster than a person living in Africa; almost six times more likely than someone in Latin America and the Caribbean, and almost 30 times more likely than a person living in North America or Europe (ESCAP, 2012a). All regions of the world are projected to experience varying impacts because of climate change. In Asia and the Pacific, increases in flooding, heat-related mortality, and drought-related water and food shortages have been identified as the main risks. If current climate change and development patterns continue, by 2100 , hundreds of millions of people, most of them in the coastal areas of East, South-East and South Asia, may be displaced unless adaptation measures are put in place. Each degree of warming is projected to decrease renewable water resources by at least 20 per cent for an additional 7 per cent of the global population, adding to the risk faced by millions of vulnerable people (IPCC, 2014). It is evident that climate change impacts, if not effectively managed, may breach ecological tipping points, which would then have magnifying effects on interrelated socioeconomic and environmental systems, with a reach far beyond national borders (IPCC, 2012).

At the same time, the economic damage caused by disasters has grown. The financial impact on cities in the region will be significant. According to recent data, costs from major flood events will likely be counted in the billions of dollars with potential serious impacts on national GDP (World Bank, 2010), as well as on the lives of poorer and marginalized communities, in particular. The international community, multilateral development banks and United Nations funds and programmes are working to support delivery of and direct access to existing and pledged international climate finance. However, international flows alone will not be sufficient to meet the growing demand for climate mitigation and adaptation finance. Filling the growing "climate financing gap" not only requires identifying alternative and innovative sources of funds from both the public and private sectors, but also developing appropriate institutional arrangements and policy landscapes to redirect existing financial flows towards climate mitigation and adaptation activities that also deliver on sustainable development priorities. ${ }^{2}$

ESCAP defines Green Growth as economic progress that fosters environmentally sustainable, lowcarbon and socially inclusive development. 
In the light of this, the present paper first touches on the evolution of the climate finance landscape and outlines the current state of play of global sources of climate finance. In the absence of an internationally acknowledged definition of climate finance, in this paper, the United Nations Framework Convention on Climate Change (UNFCCC) definition is used, which is "local, national or transnational financing, which may be drawn from public, private and alternative sources of financing" (UNFCCC, 2014a) and which target low-carbon and climate-resilient development. The discussion covers a variety of international and national actors, including development finance institutions, international climate funds, governments and relevant government agencies. Data regarding global finance flows are mostly drawn from the Climate Policy Initiative (CPI) reports as they represent the most comprehensive source of such flows to date. Second, the paper focuses on the regional landscape of climate finance in the Asia-Pacific region, with particular attention given to active climate funds, multilateral development banks, the distribution of climate finance across countries, and national-level initiatives. Mitigation, adaptation and reduction of emissions from deforestation and degradation plus conservation (REDD+) initiatives across a variety of sectors are outlined by examining data available through the Climate Funds Update (CFU). As the analysis of regional trends undertaken is affected by the lack of coherent data, this paper focuses on selected regional experiences with the aim to shed light on relevant programmes across the region. ${ }^{3}$ Finally, the paper provides recommendations for policymakers on how to effectively address identified challenges and mobilize additional resources for climate finance across Asia and the Pacific.

\section{SETTING THE CONTEXT: THE CURRENT STATE OF CLIMATE FINANCE AT THE GLOBAL LEVEL}

The complexity of the current global landscape of climate finance (see figure 1) poses serious challenges to both policymakers and potential investors. Significant knowledge and data gaps that complicate understanding of the issue and hinder the ability to adequately address investments in climate change-related activities exist. In addition, "the cumulative gap between the level of finance needed and finance actually delivered is growing" (Buchner and others, 2014, p. 5).

The Climate Policy Initiative has been tracking and consolidating the most comprehensive estimates for climate finance, represented in the figure 2 below by the now well-known CPI spaghetti diagram. Even though the spaghetti diagram has its

3 The choice of countries and sectors is dictated by the availability of data and existing literature. 


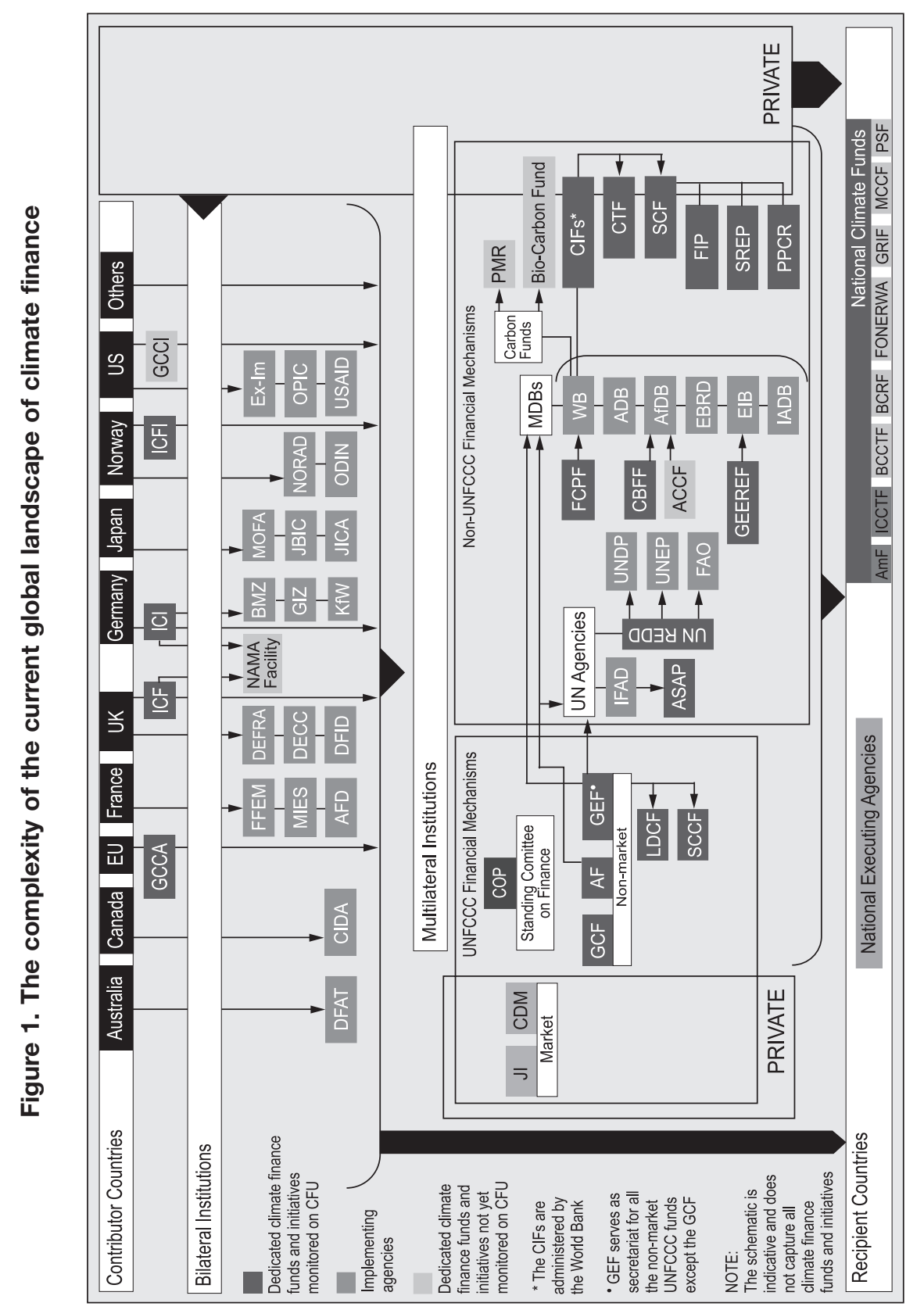

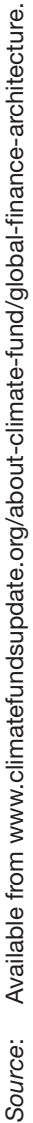




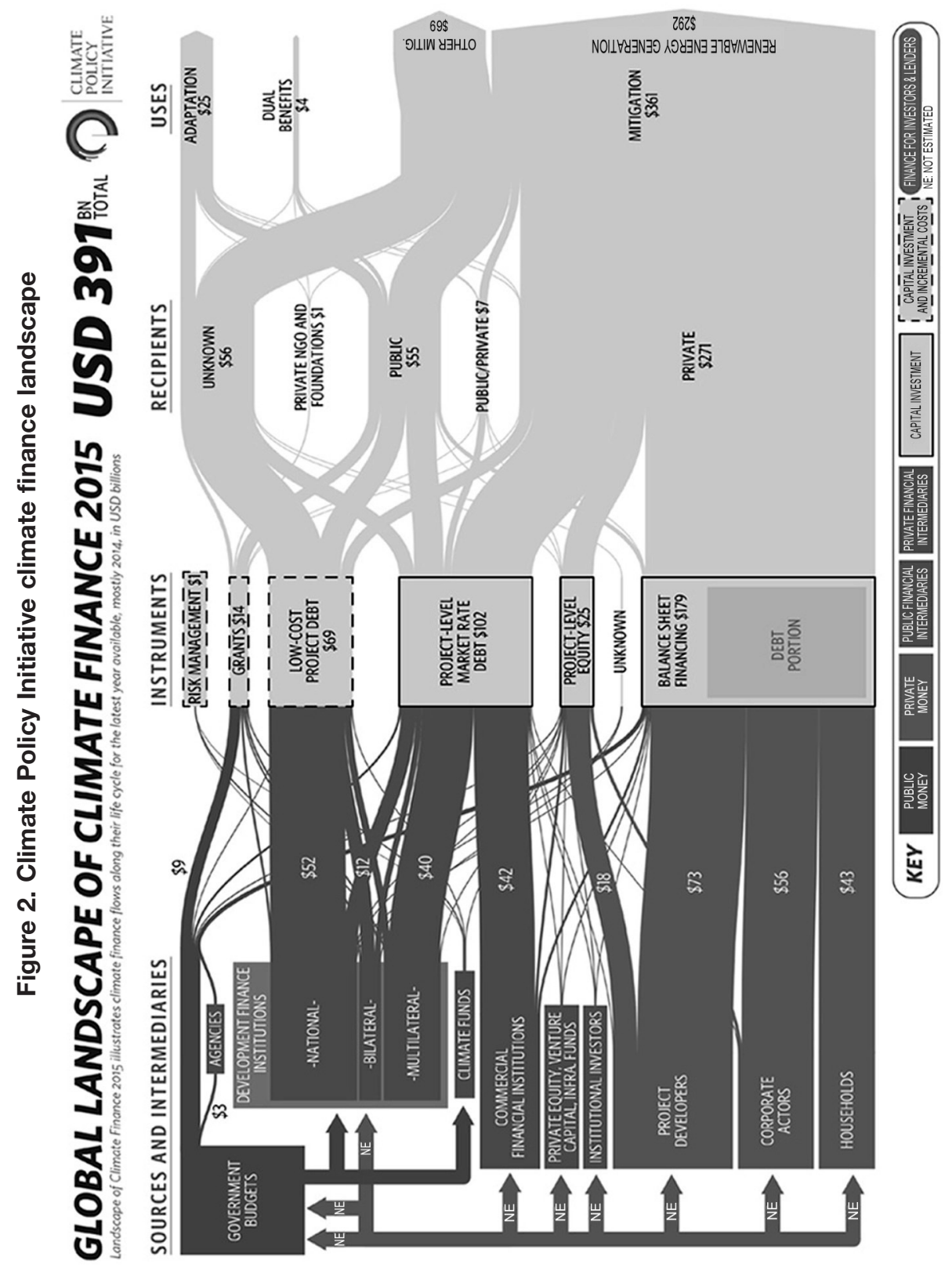

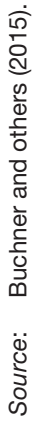


limitations (Buchner and others, 2015), ${ }^{4}$ including data availability of certain climate flows, this paper primarily uses the CPI 2015 Climate Policy Landscape to provide an overview of key elements of the current state of global climate finance. The present study is not intended to provide a comprehensive overview, but instead report on key figures to provide a broad view of the current situation.

According to latest reports issued by CPI, in 2014, annual global climate finance was $\$ 391$ billion. Despite still lagging far below the levels needed to limit warming to two degrees Celsius, ${ }^{5}$ climate finance flows have increased when compared to the 2013 level of $\$ 331$ billion. In 2013, climate finance flows were directed almost equally to developed (OECD) and developing (non-OECD) countries, with each group receiving $\$ 164$ billion and $\$ 165$ billion, respectively (Buchner and others, 2014). North-South flows accounted for $\$ 34$ billion in 2012 (Buchner and others, 2014). Developing countries invested $\$ 2$ billion in developed countries and $\$ 10$ billion in South-South cooperation (Buchner and others, 2014). However, approximately three fourths of total flows, particularly those from the private sector, were invested in their country of origin (Buchner and others, 2014) ${ }^{6}$ The 2015 report confirms these trends: about 74 per cent of total finance and 92 per cent of private investments were raised and spent within the same country. East Asia and the Pacific was the largest destination of climate finance flows accounting for $\$ 119$ billion, while Western Europe was the second main destination with $\$ 93$ billion (Buchner and others, 2015).

In 2014, the public sector contributed $\$ 148$ billion, an 8 per cent and a 10 per cent increase from 2013 and 2012 levels, respectively (Buchner and others, 2015), ${ }^{7}$ while the private sector provided $\$ 243$ billion, a record raise from 2013 levels, when

The Climate Policy Landscape tracks incremental (including grants) rather than total investment costs, and includes public framework expenditures for, among other, capacity-building, strategies and plans, MRV systems and demonstration projects, but excludes policy-induced revenues for such sources as taxes, feed-in tariffs, subsidies and concessional loans. Significant data gaps impede a full report of climate flows, including for example private sector investments in energy efficiency, including transport, land use, and adaptation. The 2015 report also does not capture "the value of public budgets dedicated to domestic climate action beyond some national DFls commitments and financing", nor "the level of climate finance that governments contribute as shareholders of companies." (Buchner and others, 2015, p. 6)

5 It is estimated that despite investments totalling \$1.095 trillion between 2011 and 2014, as much as $\$ 16.5$ trillion will be needed over the next 15 years to limit the global temperature increase to two degrees Celsius (IEA, 2015).

6 It is important to note that data limitations restrict the ability to identify private sector flows in developing countries systematically and concretely.

It is estimated that public actors in emerging and developing economies alone invested $\$ 544$ billion in 2012 on fossil fuel subsidies alone. 
private investments accounted for $\$ 193$ billion, as elaborated in table 1 below (Buchner and others, 2015). ${ }^{8}$ It is estimated that three fourths of climate finance flows were invested with the expectation of earning commercial returns (Buchner and others, 2014).

Table 1. Summary of public and private total finance flows

\begin{tabular}{lccc|ccc}
\hline Source & $\begin{array}{c}\text { Total } \\
\text { (\$ billion) }\end{array}$ & $\%$ change & $\begin{array}{c}\% \\
\text { total }\end{array}$ & $\begin{array}{c}\text { Mitigation } \\
\% \text { total }\end{array}$ & $\begin{array}{c}\text { Mixed } \\
\% \text { total }\end{array}$ & $\begin{array}{c}\text { Adation } \\
\text { (mitigation/ } \\
\text { adaptation) } \\
\% \text { total }\end{array}$ \\
\hline Public & 148 & +8 & 38 & 93 & 6 & 1 \\
\cline { 1 - 3 } Private & 243 & +26 & 62 & & \\
\hline
\end{tabular}

Source: Based on Buchner and others (2015).

Note: There is no reliable data source of project level private sector adaptation interventions.

With regard to public finance flows, direct foreign investments (DFIs) accounted for the majority investments by public actors and have contributed $\$ 131$ billion, or 33 per cent of total flows in 2014. Other public actors included multilateral and national climate funds that approved about $\$ 2$ billion for projects with mitigation and adaptation benefits. CPI further tracked $\$ 15$ billion on average of direct public contributions from government agencies and ministries in 2014 (Buchner and others, 2015). However, limited data on domestic public budgets and expenditures for climate change make it hard to capture the latter trends.

In September 2014, six multilateral development banks reaffirmed their shared commitment to take the lead in further developing climate financing. ${ }^{9,10}$ They pledged to maintain a strong focus on climate change. In particular, this included leveraging additional private sector investments and continuing to innovate and promote more

8 Private investment figures need to be explored critically as drops in private sector investments can be attributed to changing cost structures. For example, investments in solar decreased by $\$ 19$ billion, however, installed capacity increased by $5 \mathrm{GW}$, indicating that the investment decrease is largely associated with improving costs necessitating less financial investment.

9 Joint Report on MDB Climate Finance 2013, A report by a group of Multilateral Development Banks (MDBs) comprising the African Development Bank (AfDB), the Asian Development Bank (ADB), the European Bank for Reconstruction and Development (EBRD), the European Investment Bank (EIB), the Inter-American Development Bank (IDB), and the International Finance Corporation (IFC) and World Bank (WB) from the World Bank Group (WBG), September 2014. Available from www.eib.org/projects/ documents/joint-report-on-mdb-climate-finance-2013.htm.

10 ADB (2014). 
robust and transparent climate finance tracking and reporting. Those six multilateral development banks began to jointly track climate finance flows in 2011 (table 2) and since then have delivered $\$ 75$ billion in financing assistance to developing countries to support responses to climate change challenges. About 80 per cent ( $\$ 18.9$ billion) of this lending has supported mitigation activities, while 20 per cent ( $\$ 4.8$ billion) has supported adaptation measures (Buchner and others, 2014). Of the total commitments, 9 per cent, or $\$ 2.2$ billion, came from external resources, such as bilateral or multilateral donors, including the Global Environment Facility and the Climate Investment Funds.

\section{Table 2. Multilateral development banks climate finance commitments to adaptation (\$ million)}

\begin{tabular}{lcc}
\hline \multicolumn{1}{c}{ Multilateral development bank } & Adaptation 2013 & Mitigation 2013 \\
\hline African Development Bank & 473 & 768 \\
Asian Development Bank & 980 & 2272 \\
European Bank for Reconstruction & 187 & 3242 \\
$\quad$ and Development & & \\
European Investment Bank & 166 & 5058 \\
Inter-American Development Bank & 121 & 1097 \\
International Finance Corporation & 8 & 2662 \\
World Bank & 2927 & 3830 \\
Total & $\mathbf{4 8 2 6}$ & $\mathbf{1 8 9 2 8}$ \\
\hline
\end{tabular}

Source: UNFCCC (2014b).

The Global Environment Facility (GEF) Trust Fund is the primary source of grants extended to developing countries through the financial mechanism. During this GEF 5 (2010-2014) cycle, GEF had funded 787 projects on climate change mitigation for a total volume of $\$ 4.5$ billion. Funding to support adaptation by GEF is now delivered directly through the Least Developed Countries Fund (LDCF) and the Special Climate Change Fund (SCCF). As at 30 June 2014, about $\$ 1.3$ billion overall has been programmed by GEF for adaptation. The contributions from donor countries for LDCF and SCCF are voluntary and have experienced a substantial increase during the past years. Cumulative pledges to LDCF reached $\$ 900$ million in 2014 while those to SCCF were $\$ 344$ million.

Meanwhile, private sector investments have accounted for the majority of climate finance, which is highlighted in table 3 . It is estimated that private climate finance flows to developing countries are between $\$ 27$ billion and 123 billion, based 
on data from 2008 to 2011 from a variety of sources - with the caveat that private climate finance flows to developing countries are not systematically tracked, so their magnitude is highly uncertain (UNFCCC, 2014b). In 2014, "project developers"11 (Buchner and others, 2014, p. 5) invested the most, with a contribution of $\$ 92$ billion. Corporate actors invested $\$ 58$ billion of total private finance, while households (including family-level economic entities, high net worth individuals and their intermediaries) invested $\$ 43$ billion. Commercial financial institutions contributed $\$ 46$ billion (19 per cent of private investments). Private equity, venture capital, and infrastructure funds intermediated $\$ 1.7$ billion. Institutional investors spent about $\$ 0.9$ billion on renewable energy projects. The majority of these sources are being provided through a variety of instruments, namely grants, low-cost debts (including concessional loans), and capital instruments at commercial terms, such as projectlevel market rate debt, project-level equity, and balance sheet financing, as elaborated in table 4 (Buchner and others, 2014).

Table 3. Breakdown of investments by type of public and private actor, 2014

\begin{tabular}{lcc|lcc}
\hline \multicolumn{1}{c}{ Public actors } & $\begin{array}{c}\text { Total } \\
\text { (\$ billion) }\end{array}$ & $\begin{array}{c}\text { \% } \\
\text { Share }\end{array}$ & \multicolumn{1}{c}{ Private actors } & $\begin{array}{c}\text { Total } \\
\text { (\$ billion) }\end{array}$ & $\begin{array}{c}\% \\
\text { Share }\end{array}$ \\
\hline $\begin{array}{l}\text { Governments and } \\
\text { government agencies }\end{array}$ & 15 & 10 & Project developers & 92 & 38 \\
\hline $\begin{array}{l}\text { National and multilateral } \\
\text { climate funds }\end{array}$ & 2 & 1.3 & $\begin{array}{l}\text { Corporate actors \& } \\
\text { manufacturers }\end{array}$ & 58 & 24 \\
\hline DFI & 131 & 88.5 & Households & 43 & 18 \\
\hline National DFls & 66 & $\sim 51$ & $\begin{array}{l}\text { Commercial financial } \\
\text { institutions }\end{array}$ & 46 & 19 \\
\hline Multilateral & 47 & 36 & Private equity, venture \\
capital, infrastructure funds & 1.7 & $<1$ \\
\hline Bilateral & 17 & $\sim 13$ & Institutional investors & 0.9 & $<1$ \\
\hline Total & $\sim \$ 148$ & & Total & $\sim \$ 243$ & \\
\hline
\end{tabular}

Source: Based on Buchner and others (2015).

\footnotetext{
11 Project developers refer to "dedicated energy project developers, engineering, procurement and construction (EPC) contractors, utilities and independent power producers."
} 
Table 4. Climate finance flows by instruments, 2014

\begin{tabular}{lcc}
\hline \multicolumn{1}{c}{ Instruments } & Total (\$ billion) & \% Share of total climate finance \\
\hline Grants & 14 & 4 \\
Low-cost debt & 69 & 18 \\
Balance sheet financing & 178 & 46 \\
Project level market rate debt & 102 & 26 \\
Project level equity & 25 & 6 \\
\hline Total & $\mathbf{3 8 8}$ & $\mathbf{1 0 0}$ \\
\hline
\end{tabular}

Source: Based on Buchner and others (2015).

Note: $\quad{ }^{*}$ Due to data limitations, there are no details on instruments for about $\$ 0.5$ billion.

Compared to 2013, in 2014 mitigation finance has increased by $\$ 59$ billion, totalling $\$ 361$ billion, and accounting for 93 per cent of total investments; adaptation finance has instead decreased, totalling $\$ 25$ billion (Buchner and others, 2014; 2015). ${ }^{12}$ Given that more than 40 per cent of greenhouse gas emissions are caused by energy production and use, the majority of mitigation finance projects are aimed at promoting renewable energy sources (Halimanjaya and others, 2014). In particular, public mitigation finance targeted three main sectors, namely renewable energy generation (33 per cent of the total), energy efficiency (18 per cent) and sustainable transport (14 per cent). The remainder of mitigation flows were directed towards non-energy GHG reduction, low-carbon technologies, agriculture, forestry, and land use, transmission and distribution systems, and waste and wastewater management (Buchner and others, 2015). Current levels of funding are, however, deemed to be insufficient to enhance mitigation measures and CPI envisions that mitigation measures will require between $\$ 200$ billion-210 billion per annum in 2030 (Buchner and others, 2013). ${ }^{13}$

Adaptation funding reached $\$ 25$ billion in 2014 , of which 25 per cent was invested in water and wastewater management (Buchner and others, 2015). Table 5 depicts the most active funds in delivering climate adaptation finance for the period 2003-2014. However, these contributions remain low and adaptation unfortunately remains underfunded at the global level (Caravani and others, 2014). Additional investments needed are estimated to amount to several billion dollars, with at least an

12 Adaptation finance recorded is only from public sources, as there is no reliable data source for project-level private adaptation interventions, and Buchner and others (2014) also do not take into account data on domestic public budgets.

13 Figures must be seen as indicative only. 


\section{Table 5. Finance from Funds that primarily support adaptation, in millions of dollars, 2003-2014}

\begin{tabular}{lrccc}
\hline \multicolumn{1}{c}{ Adaptation finance from "Funds" } & Pledge & Deposit & Approval & Disbursement \\
\hline Adaptation Fund (AF) & 323.05 & 186.48 & 166.36 & 29.14 \\
Least Developed Countries Fund (LDCF) & 536.65 & 435.46 & 286.73 & 126.63 \\
Special Climate Change Fund (SCCF) & 241.61 & 196.40 & 147.25 & 100.23 \\
$\begin{array}{l}\text { Pilot Program for Climate Resilience } \\
\quad \text { (PPCR) }\end{array}$ & 1119.00 & 804.80 & 317.48 & 8.00 \\
$\quad$ Global Climate Change Alliance (GCCA) & 385.36 & 365.36 & 296.81 & 130.99 \\
\hline
\end{tabular}

Source: Based on Schalatek and others (2012).

additional $\$ 28$ billion-67 billion of estimated required flows to developing countries (Buchner and others, 2013).

To this end, the Green Climate Fund has recently committed to devote 50 per cent of its funding to adaptation measures, starting from 2015, with half of it going to small island developing States, least developed countries and African States, to help address the problem of insufficient funding for adaptation. In addition to mitigation and adaptation finance, since $2008, \$ 2.81$ billion has been pledged to five multilateral climate funds to support REDD+. ${ }^{14}$ However, the future of those mechanisms still remains highly uncertain. Encouragingly, pledges were made at the United Nations Climate Summit in 2014 for additional REDD+ finance and as 201480 per cent of the total funding pledged has been deposited.

On the one hand, climate funds, such as GEF, LDCF and SCCF, as well as the Climate Investment Funds (CIFs) of the World Bank, ${ }^{15}$ successfully dispensed funds for climate finance by promoting projects that have the potential to reduce emissions and increase resilience to climate change. Thus, for example, mitigation finance has targeted middle-income countries where emissions are already high and growing; poor and vulnerable countries have also been specifically targeted by climate funds that provide support for responsible ministries in investment planning and financial-

\footnotetext{
14 REDD-plus activities are located in developing countries and are funded by a combination of domestic and developed country finance.

15 The Climate Investment Funds include four key programmes that held 63 developing countries pilot low-emissions and climate resilient development including the \$5.3-billion Clean Technology Fund (CTF), the \$1.2-billion Pilot Program Climate Resilience (PPCR), the-\$785 million Forest Investment Program (FIP) and the \$796 million Scaling Up Renewable Energy in Low Income Countries Program (SREP). Available from www.climateinvestmentfunds.org/cif/.
} 
management decisions. On the other hand, however, these funds have not always been dispersed efficiently, mostly because some programmes were not carefully designed to target national circumstances. Therefore, it is clear that "a focus on the underlying policy, regulatory and enabling environment in developing interventions is needed alongside efforts to make large investments" (Nakhooda and others, 2014, p. 72).

\section{THE STATE OF CLIMATE FINANCE IN THE ASIA-PACIFIC REGION}

Asia and the Pacific is increasingly responsible for rising levels of greenhouse gas emissions despite the extensive socioeconomic impacts climate change has on the region. While per capita emissions are still low in most countries, the economic and population growth in major Asian economies has led to an increasing need for energy, especially from cheap and readily available fossil fuels. Estimates suggest that the Asia-Pacific region, with a 6 per cent annual growth rate, has the potential to account for 44 per cent of total global GDP by 2035 (ADB, 2013a). In this "Asian Century" scenario, the region's share of world energy consumption is projected to rise rapidly from about 33 per cent in 2010 (one third of world consumption), to up to 56 per cent by 2035 (ADB, 2013a). In 2035, China and India alone will account for 70 per cent of total electricity generated. Demand for coal in Asia and the Pacific is projected to increase by 52.8 per cent from 2010 to 2035, to reaching 3.5 billion tons of oil equivalents (Mtoe) (ADB, 2013b). As demand for coal, oil and other resources increases rapidly, carbon dioxide $\left(\mathrm{CO}_{2}\right)$ emissions are projected to increase from 13.4 billion tons of $\mathrm{CO}_{2}$ in 2010 to 22.1 billion tons of $\mathrm{CO}_{2}$ in 2035, growing at an annual rate of 2.0 per cent, under business as usual scenarios (ADB, 2013b).

The region's prospect for pursuing higher, inclusive and sustained growth, as well as reducing poverty and addressing inequalities, critically depends on its capacity to adapt its development patterns to those that are low carbon, resource efficient and that sustainably manage natural resources while delivering on inclusive growth necessary for poverty eradication. As rising and increasingly volatile commodity prices are becoming the "new normal" (ESCAP, 2013), the region cannot sustain its resource intensive growth pattern that currently uses three times more resources than world average per unit of GDP (ESCAP, 2012b).

One of the key challenges in undertaking this transformation is availability and access to climate finance. A report from UNFCCC estimates that additional investments and financial flows needed in order to address climate change in 2030 would amount to 0.3-0.5 per cent of global GDP and 1.1-1.7 per cent of global investment (UNFCCC, 2008). It is estimated that the energy sector alone will require 
new investments of about $\$ 19.9$ trillion under an alternative approach to business-asusual scenarios (ADB, 2013a).

Obtaining a comprehensive picture of the state of climate finance in the Asia-Pacific region is complicated by the fact that most governments have their own climate change plan as well as different institutional arrangements to coordinate climate change actions (Haites, 2014). Some countries also have independent mechanisms to fund adaptation and mitigation measures. In addition, private climate finance flows to developing countries are not systematically tracked, so their magnitude is highly uncertain (UNFCCC, 2014b). Furthermore, some countries devote significant domestic resources to climate change, while others rely almost entirely on bilateral and multilateral finance (UNFCCC, 2014b). The landscape presented below seeks to highlight some of the key flows that have been tracked in the region to date, as well as key country-level initiatives to mobilize climate finance.

\section{Finance flows from international climate funds}

Currently, twenty-two climate funds and initiatives are active in the region, which have approved a total of $\$ 3.35$ billion for projects, with $\$ 1.25$ billion approved for new projects in 2013 alone (Barnard and others, 2014). Despite concerted efforts from a variety of funds and initiatives, the distribution of climate finance flows within the region has been uneven. Over two thirds of the climate finance directed to Asia and the Pacific since 2003 has supported mitigation initiatives, while the remaining funding supported adaptation activities, REDD+ and multiple focuses programmes (Buchner and others, 2013). The most recent data from CFU show that 32 countries $^{16}$ in the region have received more than a quarter of total public climate finance from dedicated climate funds. China, India and Indonesia alone have received almost half, approximately 46 per cent of total mitigation and adaptation funding approved by dedicated climate funds for the region since 2003.

The Asia-Pacific region received 31.1 per cent of total mitigation funding from climate funds active in the region, with Indonesia being the largest recipient, accepting \$382.86 million approved for mitigation activities (Halimanjaya and others, 2014). China, India, Indonesia, the Philippines and Thailand together received 82 per cent, or $\$ 1.7$ billion, of the total amount approved for mitigation in the region. CTF,

\footnotetext{
16 In this case, Climate Funds Update follows the World Bank classification of countries in East Asia and the Pacific and South-Asia, which includes: American Samoa, Cambodia, China, Fiji, Indonesia, Kiribati, Democratic Republic of Republic of Korea, Lao People's Democratic Republic, Malaysia, Marshall Islands, Micronesia (Federated States of), Mongolia, Myanmar, Palau, Papua New Guinea, Philippines, Samoa, Solomon Islands, Thailand, Timor-Leste, Tuvalu, Tonga, Vanuatu, Viet Nam; and Afghanistan, Bangladesh, Bhutan, India, Maldives, Nepal, Pakistan and Sri Lanka.
} 
Figure 3. Top 10 recipient countries in the Asia-Pacific region by amount of funding approved ( $\$$ million)

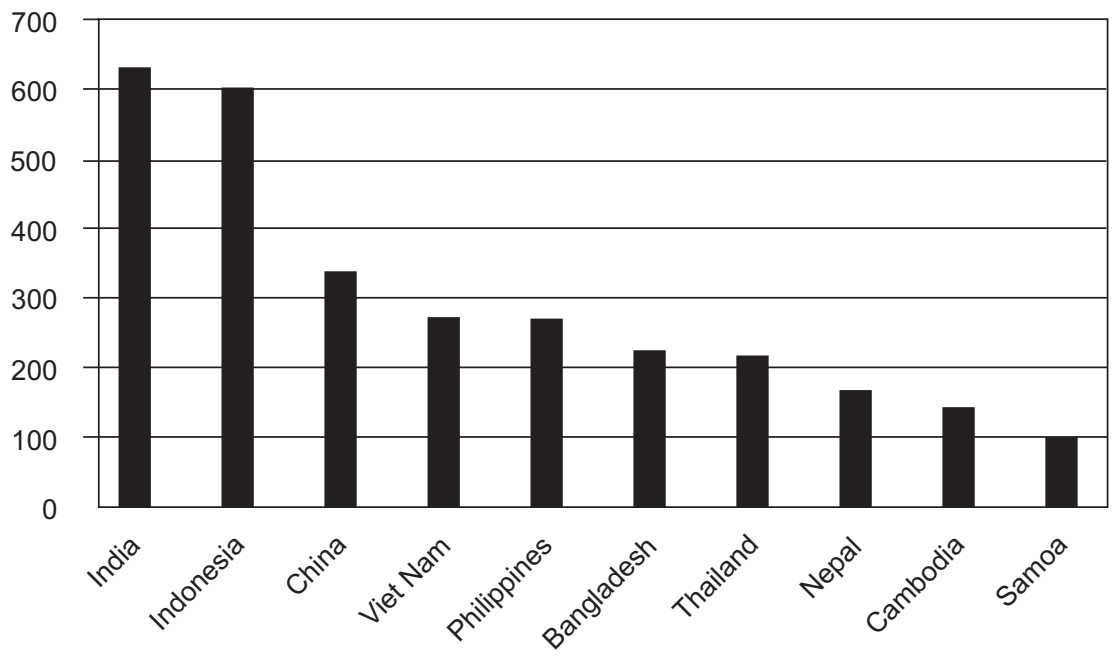

Source: Based on CFU. See www.climatefundsupdate.org/regions/asia-pacific (accessed November 2015).

Figure 4. Focus areas in East Asia and the Pacific and in South Asia

Focus areas in East Asia and the Pacific

Focus areas in South Asia

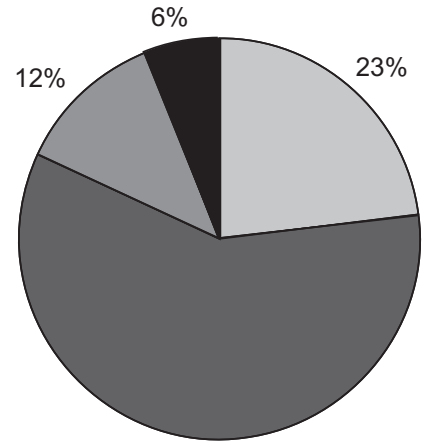

$59 \%$

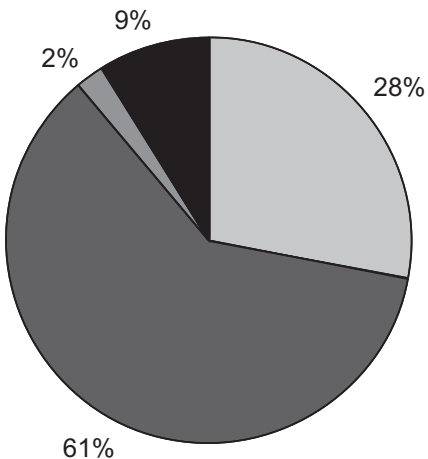

\begin{tabular}{|ll|}
\hline Adaptation & Mitigation - general \\
Mitigation - REDD+ & $\square$ Multiple focuses \\
\hline
\end{tabular}

Source: Based on CFU. See www.climatefundsupdate.org/regions/asia-pacific (accessed November 2015). 
Figure 5. Top active funds by data available for East Asia and the Pacific and for South Asia (\$ million)

Top funds supporting East Asia and the Pacific by amount approved

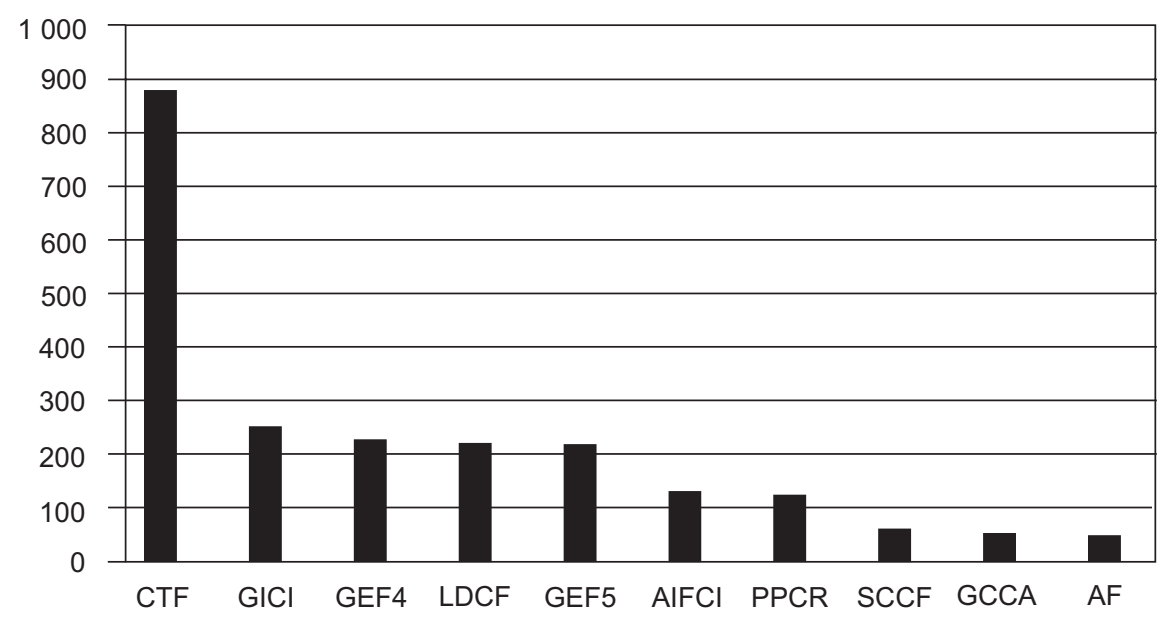

Top funds supporting South Asia by amount approved

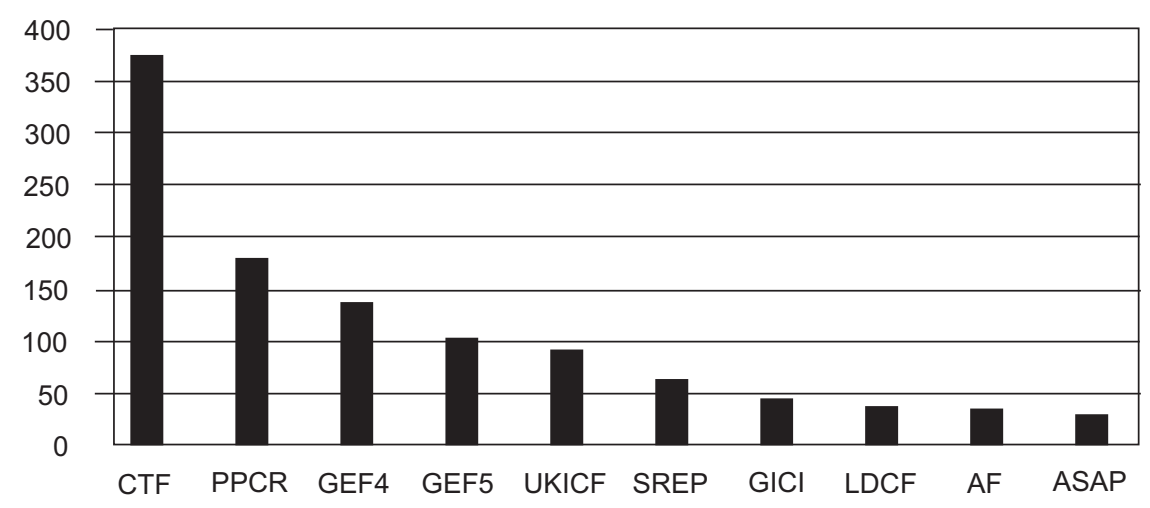

Source: Based on CFU. See www.climatefundsupdate.org/regions/asia-pacific (accessed November 2015). 
under the World Bank CIFs, has provided the majority, or $\$ 706$ million, of newly approved mitigation finance.

Sixty-two per cent of total climate finance from funds extended to the AsiaPacific region since 2003 has supported mitigation activities (Barnard and others, 2015). On average, most of mitigation finance is being directed towards countries with higher $\mathrm{CO}_{2}$ intensity, larger carbon sinks, lower per capita GDP and good governance (Haites, 2014, p. 34). Most mitigation funding supports large-scale renewable energy, energy efficiency and transport projects. SREP is an exception to this as it is supporting decentralized renewable energy and energy access programmes in Nepal, Maldives and Vanuatu for a total approved amount of almost \$63 million (Barnard and others, 2014).

During the period 2003-2015, the Asia-Pacific region received 17 per cent of total adaptation finance (Canales Trujillo and others, 2015) The \$346 million in adaptation finance approved in 2013 represents only 28 per cent of the total increase of financing for the whole region. Since its establishment in 2008, CTF has approved more than $\$ 1.20$ billion for twenty projects across the region, mostly through concessional loans (Barnard and others, 2015). ${ }^{17}$ As for adaptation, the largest amounts are being provided by PPCR, ${ }^{18}$ which has approved $\$ 857$ billion to support adaptation projects, of which 17 per cent was invested in East Asia and the Pacific, and 14 per cent in South Asia (Canales Trujillo and others, 2015). Adaptation finance flows tend to go to more vulnerable countries. However, vulnerability alone does not explain the allocation of those funds. Nonetheless, approved finance for projects in vulnerable countries, particularly the small Pacific island States, has arguably been modest. The Cook Islands, Fiji, Kiribati, Marshall Islands, Micronesia (Federated States of), Palau, Samoa, Solomon Islands, Tonga, Tuvalu and Vanuatu altogether have received only 4.6 per cent ( $\$ 155$ million) of the total amount approved for the Asia-Pacific region, primarily for adaptation activities (Normand and others, 2014). The Asia-Pacific region has only received 7 per cent of the total amount of REDD+ finance approved between 2008 and 2015, with Indonesia being the largest recipient in the region, mostly through bilateral relationships with Norway and Australia (Norman and others, 2015).

\footnotetext{
17 Further information on such projects can also be found here: www.climateinvestmentfunds.org/cif/ node/2.

18 More information on the PPCR can be found here www.climateinvestmentfunds.org/cif/ Pilot_Program_for_Climate_Resilience.
} 
Table 6. Funds active in East Asia and the Pacific and in South Asia

\begin{tabular}{|c|c|c|c|}
\hline Fund & $\begin{array}{l}\text { Year of } \\
\text { initiation }\end{array}$ & $\begin{array}{l}\text { South Asia - } \\
\text { amount } \\
\text { approved } \\
\text { (in \$ million) }\end{array}$ & $\begin{array}{c}\text { East Asia } \\
\text { and Pacific - } \\
\text { amount } \\
\text { approved } \\
\text { (in \$ million) }\end{array}$ \\
\hline \multicolumn{4}{|l|}{ Adaptation Fund Board (UNFCCC Kyoto Protocol) } \\
\hline Adaptation Fund (AF) & 2009 & 24.1 & 43.6 \\
\hline \multicolumn{4}{|l|}{ Brazilian Development Bank } \\
\hline Amazon Fund & 2009 & - & 53.5 \\
\hline \multicolumn{4}{|l|}{ Indonesia's National Development Planning Agency } \\
\hline Indonesia Climate Change Trust Fund (ICCTF) & 2010 & - & 9.5 \\
\hline \multicolumn{4}{|l|}{ UNDP } \\
\hline Millennium Development Goals Achievement Fund & 2006 & 5.0 & 20.0 \\
\hline UN-REDD Programme & 2008 & 6.3 & 24.4 \\
\hline \multicolumn{4}{|l|}{ World Bank } \\
\hline Clean Technology Fund (CTF) & 2008 & 375.0 & 888.7 \\
\hline Forest Carbon Partnership Facility (FCPF) & 2008 & 3.6 & 11.5 \\
\hline Forest Investment Program (FIP) & 2009 & - & 19.3 \\
\hline $\begin{array}{l}\text { Scaling Up Renewable Energy in Low } \\
\text { Income Countries Program (SREP) }\end{array}$ & 2009 & 66.1 & 0.6 \\
\hline Pilot Program for Climate and Resilience (PPCR) & 2008 & 170.0 & 168.4 \\
\hline \multicolumn{4}{|l|}{ The Global Environment Facility (GEF) } \\
\hline Special Climate Change Fund (SCCF) & 2001 & - & 70.1 \\
\hline Least Developed Countries Fund (LDCF) & 2002 & 77.6 & 143.2 \\
\hline Strategic Priority on Adaptation (SPA) (from GEF4) & 2004 & 6.9 & 3.1 \\
\hline GEF4 & 2006 & 137.7 & - \\
\hline Global Environmental Facility (GEF4) & & - & 297.5 \\
\hline Global Environment Facility (GEF5) & 2010 & 90.0 & - \\
\hline GEF 5 & & - & 268.6 \\
\hline Global Environmental Facility (GEF6) & & - & 9.8 \\
\hline \multicolumn{4}{|l|}{ The European Commission } \\
\hline $\begin{array}{l}\text { Global Energy Efficiency and Renewable Energy } \\
\text { Fund (GEEREF) }\end{array}$ & 2006 & - & 85.3 \\
\hline Global Climate Change Alliance (GCCA) & 2007 & 375.0 & 84.8 \\
\hline \multicolumn{4}{|l|}{$\begin{array}{l}\text { The International Fund for Agricultural } \\
\text { Development (IFAD) }\end{array}$} \\
\hline $\begin{array}{l}\text { Adaptation for Smallholder Agriculture Programme } \\
\text { (ASAP) }\end{array}$ & 2012 & 30.0 & 27.0 \\
\hline
\end{tabular}

Source: Based on CFU. Available from www.climatefundsupdate.org/regions/asia-pacific. 


\section{Finance from multilateral development banks}

Table 7 provides figures for multilateral development banks climate finance delivered to East Asia and the Pacific, non-European Union and Central Asia and South Asia in 2013 (in US\$ million).

\section{Table 7. Climate Finance delivered by multilateral development banks to East Asia and the Pacific, South Asia, ${ }^{a}$ and non-European Union and Central Asian countries ${ }^{b}$}

\begin{tabular}{|c|c|c|c|c|c|c|c|c|c|c|c|c|c|c|}
\hline \multirow{4}{*}{ Region } & \multicolumn{6}{|c|}{$\begin{array}{l}\text { Multilateral development } \\
\text { bank resources }\end{array}$} & \multicolumn{6}{|c|}{ External resources } & \multirow{4}{*}{$\begin{array}{c}\text { Total } \\
\text { multilateral } \\
\text { development } \\
\text { bank climate } \\
\text { finance } \\
\text { per region }\end{array}$} & \multirow{4}{*}{$\begin{array}{c}\text { Total } \\
\text { multilateral } \\
\text { development } \\
\text { bank finance } \\
\text { per region }\end{array}$} \\
\hline & \multicolumn{4}{|c|}{$\begin{array}{l}\text { Investments and } \\
\text { technical assistance }\end{array}$} & \multirow{2}{*}{\multicolumn{2}{|c|}{$\begin{array}{l}\text { Policy- } \\
\text { based } \\
\text { instru- } \\
\text { ments }\end{array}$}} & \multicolumn{4}{|c|}{$\begin{array}{l}\text { Investments and } \\
\text { technical } \\
\text { assistance }\end{array}$} & \multirow{2}{*}{\multicolumn{2}{|c|}{$\begin{array}{l}\text { Policy- } \\
\text { based } \\
\text { instru- } \\
\text { ments }\end{array}$}} & & \\
\hline & \multicolumn{2}{|c|}{ Public } & \multicolumn{2}{|c|}{ Private } & & & \multicolumn{2}{|c|}{ Public } & \multicolumn{2}{|c|}{ Private } & & & & \\
\hline & M & A & M & A & M & A & M & A & M & A & $\mathbf{M}$ & A & & \\
\hline $\begin{array}{l}\text { East Asia } \\
\text { and the } \\
\text { Pacific }\end{array}$ & 1438 & 978 & 798 & 0 & 35 & 35 & 644 & 60 & 276 & 0 & 1 & 0 & 4308 & 19016 \\
\hline $\begin{array}{l}\text { South } \\
\text { Asia }\end{array}$ & 1399 & 847 & 514 & 0 & 50 & 50 & 120 & 110 & 30 & 0 & 1 & 0 & 3120 & 16600 \\
\hline $\begin{array}{l}\text { Non- } \\
\text { European } \\
\text { Union } \\
\text { and } \\
\text { Central } \\
\text { Asia }\end{array}$ & 2403 & 214 & 2218 & 46 & 10 & 0 & 70 & 42 & 105 & 0 & 0 & 0 & 5117 & 224463 \\
\hline Total & & & & & & & & & & & & & 12545 & 260079 \\
\hline
\end{tabular}

Source: Adapted from Joint Report on MDB Climate Finance 2013. Available from www.eib.org/attachments/ documents/joint_report_on_mdb_climate_finance_2013.pdf.

Note: $\quad \mathrm{M}=$ Mitigation, $\mathrm{A}=$ Adaptation.

a Similar to CFU, EIB also follows the World Bank classification of countries in East Asia and the Pacific and in South Asia. Available from www.eib.org/attachments/documents/joint_report_on_mdb_ climate_finance_2013.pdf.

${ }^{\mathrm{b}}$ According to EIB, countries considered as part of non-European Union and Central Asia countries are: Albania, Armenia, Azerbaijan, Belarus, Bosnia and Herzegovina, Georgia, Kazakhstan, Kyrgyzstan, Kosovo, Montenegro, Republic of Moldova, Russian Federation, Serbia, the Former Yugoslav Republic of Macedonia, Turkey, Tajikistan, Turkmenistan, Ukraine and Uzbekistan. Available from www.eib.org/ attachments/documents/joint_report_on_mdb_climate_finance_2013.pdf. 
Of the total adaptation finance provided by multilateral development banks in 2013, East Asia and the Pacific received $\$ 1.072$ billion and South Asia received $\$ 1.008$ billion. As for the multilateral development banks mitigation finance, \$3.236 billion was disbursed to East Asia and the Pacific and \$2.113 to South Asia (MDBs, 2013). Among multilateral banks, ADB is the Asian regional development bank; it is supporting climate change mitigation and adaptation initiatives throughout Asia and the Pacific through a variety of initiatives, including, among them: the ADB internal Climate Change Fund; trust funds managed by $A D B$, which receive contributions from developed countries (Australia, Canada, Japan, Norway, Spain, Sweden and the United Kingdom); the Global Carbon Capture and Storage Institute; and climate funds that are externally managed but can be accessed by ADB. As of the end of 2013, the total amount of externally managed climate funds that ADB has managed and/or has had access to amounts to $\$ 1.5$ billion (Haites, 2014, p. 38).

\section{Subregional climate finance initiatives}

Subregional organizations are increasingly leveraging the benefits of cooperation to address the large gaps in finance and action in the region on mitigation and adaptation. Through the creation of subregional frameworks for action on climate change, subregional bodies are setting the stage for concerted action at the national level towards climate change mitigation and adaptation. Subregional frameworks also offer a key opportunity to facilitate partnership building and engagement on strengthening the science-policy interface through scientific partnerships, capacitybuilding, information and even technology exchange among subregional organizations. With support from subregional and regional partners comprehensive, multisectoral and strategic road maps for action can be developed and jointly implemented. With these strong policy signals from the subregion, climate finance can be directed to appropriate investments for low-carbon development. Also, importantly, subregional consensus can ensure that important issues of concern are raised effectively at global negotiations. In addition, G20 leaders are poised to make a significant contribution to climate change finance, thanks to their influential position, by engaging in a meaningful discussion on climate change. During the twenty-first Conference of the Parties (COP21), held in Paris from 30 November to 11 December 2015, they reached an agreement on the reduction of climate change (the Paris Agreement), which will become legally binding only if signed by at least 55 countries over the next two years. ${ }^{19}$ One of the most pressing questions that leaders also need to keep address is where will the money come from and where it will be spent (Jorgensen, 2013). In another forum, which was held in Brussels on 4 and 5 June

19 See www.cop21.gouv.fr/en/ for more information. 
2014, G7 leaders committed, from their side, to take concrete action to address climate change by pursuing low-carbon economies and taking the lead in collecting resources to meet the target of mobilizing $\$ 100$ billion per year by $2020 .^{20}$

One example ${ }^{21}$ of such initiatives is being undertaken by the Association of Southeast Asian Nations (ASEAN), which has been active in addressing climate change, including by issuing declarations/statements related to climate change in 2007, 2009, 2010, 2011 and 2014 that express the subregion's common understanding and aspirations towards climate change and their resolve to achieve an ASEAN community resilient to climate change through national and regional actions, including by technology transfer, capacity-building and financial assistance from developed countries to support nationally appropriate mitigation actions (NAMAs) and Intended Nationally Determined Contributions (INDCs). The statements highlight the importance of climate change mitigation and adaptation actions that are consistent with broader sustainable development goals. The ASEAN Socio-Cultural Community (ASCC) Blueprint 2009-2015 strategic objectives are to "enhance regional and international cooperation to address the issue of climate change and its impacts on socioeconomic development, health and the environment, in ASEAN member States through implementation of mitigation and adaptation measures...". The ASEAN MultiSectoral Framework on Climate Change: Agriculture, Fisheries and Forestry towards Food Security (AFCC) was endorsed by the ASEAN Ministerial Meetings on Agriculture and Forestry (AMAF) in November 2009. The overall aim of AFCC is to contribute to food security through sustainable, efficient and effective use of land, forest, water and aquatic resources by minimizing the risks and impacts of and the contributions to climate change. The ASEAN Working Group on Climate Change (AWGCC) was established in 2009 and the Action Plan on Joint Response to Climate Change was developed in 2012. Key actions include: encourage an ASEAN common understanding to engage in joint efforts; develop an ASEAN climate change initiative (ACCl); facilitate information/knowledge exchange, including transfer of technology; engage with the international community; develop regional strategies to enhance capacity for low carbon economies; enhance collaboration to address climate related hazards; develop observation systems and conduct policy and scientific studies;

\footnotetext{
20 The Brussels G7 Summit Declaration. Available from www.bundesregierung.de/Content/DE/ _Anlagen/G8_G20/G7-2014-06-05-abschlusseklaerung-eng.pdf?_blob=publicationFile\&v=2.

21 Other similar initiatives are the South Asian Association for Regional Cooperation (SAARC) (http:// saarc-sec.org/areaofcooperation/cat-detail.php?cat_id=54); the Pacific Island Forum Secretariat (PIFS) (www.forumsec.org/pages.cfm/strategic-partnerships-coordination/climate-change/?printerfriendly=true) and the Secretariat of the Pacific Regional Environment Programme (SPREP) (www.sprep.org/ attachments/Publications/PIFACC-ref.pdf); and www.pacificclimatechange.net/index.php/component/ content/article/400-announcements/7529-call-rtsm.
} 
promote public awareness and advocacy for increased stakeholder engagement; and promote a win-win synergy between climate change and economic development. ${ }^{22}$

\section{National climate finance flows}

The local dimension of climate finance is of great importance, not only because of the intrinsically local nature of climate change effects, but also on account of the crucial role of local policymakers and practitioners in achieving results on the ground. Country systems were devised during the Global Forum on Using Country Systems to Manage Climate Change Finance, which was held in Incheon, Republic of Korea, on 2 and 3 December 2013, as a way to manage climate finance at the national level (UNDP, 2013). They combine a variety of instruments to address climate finance, including: national and local systems for planning; policy coordination and implementation; budgeting and financial management; procurement; and monitoring and evaluation. In this regard, country systems may prove to be essential resources for national governments to manage climate finance at the local level while actively engaging the private sector, non-governmental organizations and households.

Given the importance of mobilizing domestic resources according to national circumstances, climate finance needs to be defined according to country-led definitions of climate expenditures. Therefore, countries in the Asia-Pacific region have started to produce their own Climate Public Expenditure and Institutional Reviews (CPEIRs), which are aimed at helping ministries of finance, environment and planning assess how to configure national budgets in order to respond to climate change. Five countries have initiated pilot CPEIRs, namely Bangladesh (Bangladesh, 2012), Cambodia (ODI, 2012a), Nepal (Nepal, National Planning Commission, 2011), Samoa (ODI, 2012b) and Thailand (ODI, 2012c), which altogether signal that across the region, countries are becoming aware of the need to bring climate finance into national agendas as a key issue to be addressed in both the short and the long term.

Establishing a national climate fund (NCF) is another effective way to tailor coordination and strengthen national ownership of climate finance. Such mechanisms, which are already being pursued in some countries in the Asia-Pacific region, extend support in directing finance towards climate change programmes (Flynn, 2011). NCFs can help national governments focus on country-driven climate change priorities based on national realities by addressing four main goals: collecting and distributing funds to climate change-related activities that target national circumstances; facilitating the blending of public, private, multilateral and bilateral

22 http://environment.asean.org/asean-working-group-on-climate-change/; www.asean-cn.org/ltem/ 981.aspx; and http://environment.asean.org/wp-content/uploads/2015/03/ASEAN-Joint-Statement-onClimate-Change-2014.pdf. 
sources of finance; coordinating country-wide climate change programmes; and strengthening national institutions and financial management, for example through the creation of National Implementing Entities (NIEs), to deliver climate change projects. If aligned with existing national institutions and objectives, NCFs have the potential to create an effective system to translate financial opportunities into real achievements. Some countries that have set up NCFs are Indonesia (Flynn, 2011, p. 48); ${ }^{23}$ Bangladesh (Flynn, 2011, p. 49); ${ }^{24}$ and China (Flynn, 2011, p. 50). ${ }^{25}$

Furthermore, there has been increasing interest in using NAMAs as a tool for countries to promote climate change mitigation actions in the context of national sustainable development strategies. The concept of NAMA was introduced in the Bali Action Plan, which was set at the thirteenth Conference of Parties (COP13) in 2007 in Bali, Indonesia. Paragraph 1(b)(ii) calls for "(n)ationally appropriate mitigation actions by developing country Parties in the context of sustainable development, supported and enabled by technology, financing, and capacity-building, in a measurable, reportable and verifiable manner" (UNFCCC, 2007a). NAMAs include any action that is aimed to reduce emissions in developing countries and should be part of a national governmental initiative. They may include policies directed at transformational change within an economic sector or actions across a variety of sectors with a broader national focus. NAMAs are defined at two levels: (a) at the national level, as a formal submission by parties declaring their intent to curb greenhouse gas emissions in accordance with their capacity and in line with their national development goals; and (b) at the individual action level, as actions designed to help Parties meet their national mitigation objectives. ${ }^{26}$

Nationally appropriate mitigation actions can be a key instrument for implementing low-carbon sustainable development strategies, as well as for specific sectorial policies and strategies, and can help leverage financing, technology and capacity-building. Since 2010, 48 NAMA proposals have been submitted by developing countries for inclusion in appendix II of the Copenhagen Accord, ${ }^{27}$ many

23 See also www.icctf.or.id. As of 2012, ICCTF is being funded by: DFID (\$9.5 million); AusAID (\$1.4); Swedish International Development Cooperation $(\$ 332,000)$ and United Nations Development Programme $(\$ 88,000)$. Exact breakdowns can be found at www.icctf.or.id/finance-and-performance/ $\mathrm{read} / 29 /$ funding-status-2012.

\section{See also www.bccrf-bd.org.}

25 The main sources of the Chinese fund are national revenues from Chinese CDM projects and interest earned from its operation. See www.cdmfund.org/eng/index.aspx and The Case of China CDM Fund. Available from http://adaptasiapacific.org/events/regional-clinic-design-and-management-nationalclimate-funds; and China Clean Development Mechanism Fund (2011).

26 See http://unfccc.int/focus/mitigation/items/7172.php.

27 See http://unfccc.int/meetings/cop_15/copenhagen_accord/items/5265.php. 
of which are indicated as conditional on receiving appropriate support. Of these, 17 were submitted by Asia-Pacific countries. ${ }^{28}$ The content of those NAMAs are diverse, ranging from targets and goals for reducing carbon emissions to specific sectorbased actions that lead to carbon reductions, such as in energy, energy efficiency, agriculture, forestry, construction and transport sectors. The ESCAP Low Carbon Green Growth Roadmap for Asia and the Pacific (ESCAP, 2012b) highlights lowcarbon development strategies and NAMAs as key tools for green growth and provides practical examples of potential NAMAs. Although each country has different priorities in terms of the sectors and technologies needed to achieve the target, many Asian countries have now set their own target for greenhouse gas emissions or relevant indicators, including emissions intensity or energy efficiency, and are using their developed NAMAs as a first step and a key input into developing Intended Nationally Determined Contributions (INDCs). INDCs not only serve as a demonstration of national and political commitment, but they also offer the opportunity to identify and realize non-climate multiple benefits to climate mitigation and adaptation action. Such strong signals and clear communication of objectives from countries on their intended actions to climate mitigation and adaptation can stimulate climate relevant investments, technological innovation and participation by non-government stakeholders.

Finally, national development banks are considered key players in climate finance, given their capacity to leverage international funding and increase its impact and effectiveness, thanks to their field knowledge, expertise and innovative financing schemes. Furthermore, their capacity to access and coordinate international climate finance represents a key element for enhancing developing countries' effectiveness in combating climate change. Thus, collaboration with local financial institutions and finance ministries has become an essential precondition to ensure that climate finance is used efficiently to catalyse both public and private climate finance investments and promote low-carbon green economies. ${ }^{29}$ Public financial institutions, such as national development banks and central banks, can serve as effective change agents in advancing environmental sustainability solutions that can help overcome the dilemma of pursuing green policies without sacrificing economic growth in developing

\footnotetext{
28 Afghanistan, Armenia, Bhutan, China, Georgia, India, Indonesia, Kyrgyzstan, Maldives, Mongolia, Papua New Guinea, the Republic of Korea, Singapore, Tajikistan and Thailand are countries that have set NAMAs, according to the UNFCCC web page. While there may be additional NAMAs this report takes the UNFCCC page as the final count. Available from http://unfccc.int/meetings/cop_15/copenhagen_accord/ items/5265.php. Viet Nam and Malaysia also made pledges at Copenhagen (2009). Available from www.adbi.org/files/2013.06.28.book.low.carbon.green.growth.asia.pdf.
}

29 See, for example, information pertaining to the meeting entitled "The Role of National Development Banks in Mobilizing International Climate Finance", which was held in Washington, D.C. on 18 and 19 April 2012. Available from http://events.iadb.org/calendar/eventDetail.aspx?lang=En\&id=3472. 
countries. Thus, both national development banks and central banks should not miss the opportunity to focus on priority change programmes regarding three pillars, namely monetary policy, which entails encouraging innovation and adoption of green technologies; banking supervision, which concerns the exploration of both costs and opportunities arising from climate change for financial institutions; and payment systems, which point at ensuring eco-friendly products for payment systems (Lim, 2010). Within the Asia-Pacific region, several countries have been active in pursuing policies to promote green banking. Among them are Bangladesh, China, Indonesia and the Republic of Korea (ESCAP, 2014).

\section{THE WAY FORWARD FOR THE ASIA-PACIFIC REGION}

The extent of public and private climate finance needed in the Asia-Pacific region is not known because of lack of reliable data, however, it is clear that substantial gaps for financing climate mitigation and adaptation action exist. Given the impact climate change is expected to have on the region, mobilizing adequate financing is a priority for the region. In the Fifth Assessment Report of the Intergovernmental Panel on Climate Change (IPCC), the need for transformations in economic, social, technological, and political decisions and actions to enable climate-resilient pathways for sustainable development was emphasized (IPCC, 2014, pp. 1-32). The analysis of relevant country-level initiatives suggests that some key strategies can be identified for the Asia-Pacific region with regard to climate finance, are further elaborated below.

\section{Aligning climate finance and financing for sustainable development}

While countries in the region urgently need to mobilize the necessary climate finance in order to limit warming to two degrees Celsius and adapt to the impacts of unavoidable climate change, the region also faces a myriad of sustainable development challenges that must be equally prioritized. This includes not only international-level commitments, such as those proposed by the Open Working Group on Sustainable Development, and the outcomes of negotiations for the United Nations 2030 Agenda or Sustainable Development, which was adopted on 25 September 2015, but importantly, national and regional sustainable development priorities.

Aligning climate finance and sustainable development finance is, therefore, key to effectively addressing both concerns, particularly as a number of benefits can be derived in terms of sustainable development from climate mitigation and adaptation actions, and vice-versa. This alignment is considered to have positive effects on the region as "it results in a more efficient use of financial and human resources than if 
climate change and development projects are designed and implemented separately" (Haites, 2014, p. 43). Sustainable development projects have the potential of being adapted to climate change, while at the same time mitigation and adaptation measures can be conceived in a way that yields sustainable development benefits. Pursuing a national sustainable development strategy that is focused on low-carbon development is one such way to overcome the perceived trade-offs between investing in climate finance and investments in sustainable development (Haites, 2014). In the Asia-Pacific region, low-carbon green growth has been identified as one such strategy that aligns climate and sustainable development objectives.

\section{Redirecting national public finance towards climate change and sustainable development through low-carbon development strategies}

Acknowledgement of the need to align sustainable development and climate finance will prompt the question of how to invest additional resources in order to achieve both ends. Governments are emerging as key players in climate financing facilitating frameworks for climate action and investment through development of appropriate national policy and institutional frameworks, redirecting investments towards climate mitigation and adaptation, and incentivising low-carbon investments in infrastructure and industry through national development and finance institutions.

In order to cover additional investments, appropriate policies and incentives should be pursued at the national level to leverage the significant financial resources that are available to the region. Public financial institutions should facilitate a transition to low-carbon and greener economies based on national policy frameworks through developing new incentives and reorienting existing public resources to greener activities.

A successful policy framework together with government incentives and shared initiatives could prove fundamental in the region's transition to a sustainable lowcarbon green economy. It is estimated that more than $\$ 7$ trillion in foreign exchange reserves and more than $\$ 2.5$ trillion in sovereign wealth funds are available to the Asia-Pacific region. Overall, countries in Asia and the Pacific have among the highest savings in the world. As a result, there is great potential to use the region's savings, which is currently largely invested outside the region. ${ }^{30}$ Making only some of those resources available for development in the region would go a long way towards attaining climate and sustainable development objectives: using 5 per cent of the currently available Asia-Pacific regional public savings could generate more than $\$ 350$

30 Most of the region's reserves, for instance, are invested in low-yielding securities in advanced economies, particularly in United States dollar treasury securities. 
billion of additional resources. National development banks are beginning to establish specialized climate finance facilities to address mitigation and adaptation measures. Particularly, climate bonds are expected to become a growing trend (Buchner and others, 2013; USAID, 2013).

\section{Mobilizing national private sector and non-government climate finance flows}

Despite the key role of public institutions, it is clear that the public sector alone will not be able to mobilize the financial flows required to achieve mitigation and adaptation objectives. An ADB study in 2009 estimated an investment need of $\$ 8$ trillion for infrastructure alone (ADB and ADBI, 2009). Other estimates for investments to provide a robust system of social protection range between 5 and 8 per cent of GDP (ESCAP, 2013). Though national development banks are emerging as leaders in climate finance mobilization, equal attention must be directed to facilitating and incentivizing private sector finance flows for mitigation and adaptation efforts. Non-government sources are most likely to contribute an increasing share of both sustainable development and climate finance.

Domestic capital may be mobilized from different sources, such as private investors, commercial banks and public capital markets. The actual capacity of capital markets is to a large extent determined by the level of economic development of a country, and the national institutional and policy incentives that direct investments towards climate change mitigation and adaptation projects. The main challenge to be addressed in this sector is to shift these investments to low-carbon alternatives. There is also a growing need for governments to provide incentives and mitigate risks for private equity funds to invest more robustly in climate friendly lowcarbon development initiatives. To this end, policy certainty becomes crucial (UNFCCC, 2007b). Barriers specific to green investments have been identified, and include: market, institutional and policy failures that make green investments unattractive (price-gap); high risks perceptions on green markets that have long payback period, mainly due to uncertainties and lack of information (time-gap); absence of policy and/or regulatory measures to internalize climate change-related externalities (knowledge gap); low access to finance in developing countries and least developed countries in particular; and the instability of the financial systems in those countries (UNEP, 2012). Addressing this "time gap", "price-gap", "knowledge gap" and other challenges between short-term costs and long-term benefits of green investments requires collaborative action between governments and the private sector to overcome the present financial barriers and risks that restrict capital flows into green projects for climate change, thereby leading to increased investment.

While there is no one-size-fits-all policy prescription that applies to all parts of the world, common key areas to be addressed include the development of effective 
policies to create investment-grade environments or to compensate for market failures, and securing predictability and policy-certainty for investors (Maheshwari, Miller and Patel, 2013).

\section{Regional and subregional cooperation and support from the international community}

Financing for sustainable development is important in Asia and the Pacific in the light of the region's vast population, persistent high levels of poverty and the adverse environmental impacts associated with its rapid development. Greater efforts must be made to invest existing resources within the region. However, it will also be critical to raise additional resources, as outlined above. South-South cooperation, triangular cooperation and regional cooperation will form further critical complementary elements of a financial strategy in support of sustainable development in Asia and the Pacific.

The Economic and Social Commission for Asia and the Pacific is leading the way for improved regional integration and cooperation. In that regard, in the Bangkok Declaration on Regional Cooperation and Integration in Asia and the Pacific ${ }^{31}$ it was emphasized that "fostering trade, investment, economic and development cooperation among countries in Asia and the Pacific can create opportunities not only for supporting economic growth but also for achieving wider developmental objectives". ${ }^{2}$ The Commission, in the resolution, resolved to work together to pursue enhanced regional economic cooperation and integration in the following four areas: (a) moving towards the formation of an integrated market; (b) the development of seamless connectivity across the region; (c) enhancing financial cooperation for, among other things, closing infrastructure gaps across countries in the region and exploring the possibility of providing liquidity support; and (d) increasing economic and technical cooperation to address shared vulnerabilities and risks. The Working Group on Shared Vulnerabilities and Risks subsequently launched proposed key streams of action, which included, among them, the strengthening science-policypractice interface and the leveraging of economic opportunities that could arise from addressing sources of risk and vulnerabilities for including climate change adaptation efforts.

In addition, ESCAP has been working with countries in the region to develop and integrate low-carbon and sustainable development strategies into national frameworks and to enhance regional cooperation to deliver on sustainability

\footnotetext{
31 E/ESCAP/RES/70/1.
}

32 Ibid. 
objectives. Low Carbon Green Growth approaches to policy development can help countries to strategize appropriate development pathways across key sectors, such as urban development, transportation, water and energy. Low Carbon Green Growth entails instituting key budget and system reforms that, despite minimal technology and financial support, can help place developing countries on a leapfrogging path towards achieving sustainable development and reaching their climate targets.

Subregional organizations are increasingly leveraging the benefits of cooperation to address the large gaps in finance and action in the region on mitigation and adaptation. Subregional frameworks for action on climate change can provide a unified vision for countries of similar circumstance and geographic proximity to identify key priorities in line with national development strategies, develop win-win partnerships, and take action collectively to maximize impact and learning. By articulating a unified policy vision on climate change for the subregion, international and other climate finance actors can strategically channel resources to tackle priority issues. This includes financing from national public, private and other nongovernment actors. A subregional strategic vision can support improved trade and knowledge exchange, help to open up sustainable and climate investment opportunities across markets, and minimize "first-mover" risk. Also, importantly, subregional consensus can ensure that important issues of concern are raised effectively at the global negotiations.

\section{CONCLUSIONS}

There is a widening gap in the Asia-Pacific region between the amount of climate finance directed towards adaptation and mitigation of climate change and the amount of finance necessary to address these and sustainable development issues. Despite concerted efforts at the international level, climate finance mobilized by international public sources will never reach the levels required to meet investment costs to transform economies in the region to resource-efficient, low-carbon models. However, countries in the Asia-Pacific region have at their disposal a number of tools that can be utilized in addition to international finance and capacity support delivered by the international community and United Nations organizations to meet this growing demand for climate finance. The present paper has offered an overview of both the global and the Asia-Pacific climate finance landscape, thus highlighting how countries in the region are already leveraging the force of national low-carbon and climate resilient development policies to mobilize and redirect national public climate finance, as well as to incentivize private and other non-government financial flows towards low-carbon development. 
Aligning climate and sustainable development national strategies, including through national low-carbon green growth sustainable development strategies, can transform the deficit of climate finance from a burden to a potential opportunity to facilitate a transformation in the region to ensure poverty reduction and economic growth. Aligned national strategies and supporting policy frameworks and interventions can help to incentivize action from a wide range of public and private stakeholders and mobilize adequate investments in climate and sustainable development in the region.

As the world began moving towards a binding global agreement on climate change at the UNFCCC COP 21 in Paris in December 2015, the Asia-Pacific region has emerged as a key driver for mitigation and innovator for adaptation. Subregional and regional frameworks can help to coordinate national actions, facilitate information and capacity exchanges, and strategically orient climate finance towards priority areas for mitigation and adaptation. In addition, regional cooperation can provide the common frameworks to facilitate information, low-carbon market and trade network development, and technology exchanges among countries in the Asia-Pacific region as they work towards the common goal of limiting global warming. 


\section{REFERENCES}

Asian Development Bank (ADB) (2012). Green Urbanization in Asia: Key Indicators for Asia and the Pacific 2012. Manila

(2013a). Asian Development Outlook 2013 Highlights. Manila. Available from www.adb.org/ sites/default/files/publication/30205/ado2013-highlights_0.pdf.

(2013b). Energy Outlook for Asia and the Pacific. Manila. Available from www.adb.org/ publications/energy-outlook-asia-and-pacific-2013.

(2014). Multilateral development banks agree to reinforce climate financing in advance of UN Summit. Available from www.adb.org/news/multilateral-development-banks-agreereinforce-climate-financing-advance-un-summit.

Asian Development Bank (ADB), and Asian Development Bank Institute (ADBI) (2009). Infrastructure for a Seamless Asia. Tokyo: ADBI. Available from www.adbi.org/files/2009.08.31.book. infrastructure.seamless.asia.pdf.

Bangladesh (2012). Bangladesh Climate Public Expenditure and Institutional Review. Dhaka: Ministry of Planning. Available from http://climatefinance-developmenteffectiveness.org/ publications.

Barnard, Sam, and others (2014). Climate finance regional briefing: Asia and the Pacific. Climate Finance Fundamentals, No. 8 (November). London: Overseas Development Institute.

(2015). Climate finance regional briefing: Asia. Climate Finance Fundamentals, No. 8 (December). London, Overseas Development Institute.

Buchner, Barbara, and others (2013). Global landscape of climate finance 2013. Climate Policy Initiative. Available from http://climatepolicyinitiative.org/publication/global-landscape-ofclimate-finance-2013/.

(2014). Global landscape of climate finance 2014. Climate Policy Initiative. Available from http://climatepolicyinitiative.org/publication/global-landscape-of-climate-finance-2014/.

(2015). Global landscape of climate finance 2015. Climate Policy Initiative. Available from http://climatepolicyinitiative.org/publication/global-landscape-of-climate-finance-2015/.

Canales Trujillo, Nella, and others (2015). Climate finance thematic briefing: adaptation finance. Climate Finance Fundamentals, No. 3 (December). London: Overseas Development Institute.

Caravani, Alice, and others (2014). Climate finance thematic briefing: adaptation finance. Climate Finance Fundamentals, No. 3 (December). London: Overseas Development Institute.

China Clean Development Mechanism Fund (2011). China CDM Fund Annual Report 2011. Beijing.

Flynn, Cassie (2011). Blending Climate Finance Through National Climate Funds: A Guidebook for the Design and Establishment of National Funds to Achieve Climate Change Priorities. New York: UNDP.

Haites, Erik (2014). Aligning climate finance and development finance for Asia and the Pacific: potential and prospects. Sustainable Development Working Paper Series, No. 33. Manila: ADB.

Halimanjaya, Aidy, and others (2014). Climate finance thematic briefing: mitigation finance. Climate Finance Fundamentals, No. 4 (November). London: Overseas Development Institute. 
Intergovernmental Panel on Climate Change (IPCC) (2012). Managing the Risks of Extreme Events and Disasters to Advance Climate Change Adaptation: Special Report of the Intergovernmental Panel on Climate Change, C.B. Field and others, eds. Cambridge and New York: Cambridge University Press.

(2014). Summary for policymakers. In Climate Change 2014: Impacts, Adaptation, and Vulnerability. Part A: Global and Sectoral Aspects. Contribution of Working Group II to the Fifth Assessment Report of the Intergovernmental Panel on Climate Change, C.B. Field and others, eds. Cambridge and New York: Cambridge University Press.

International Energy Agency (IEA) (2015). World Energy Outlook Special Report. Energy and Climate Change. Paris. Available from www.iea.org/publications/freepublications/publication/weo2015-special-report-energy-climate-change.html.

Jorgensen, Hugh (2013). The G20, climate financing and the UNFCCC COP21 meeting in Paris. Sydney: Lowy Institute for International Policy. Available from www.lowyinstitute.org/files/ jorgensen_the_g20_climate_financing_and_the_unfccc_cop21_meeting_in_paris.pdf.

Lim, C.S. Vincent (2010). Greener central banks: exploring possibilities. Staff Paper, No. 76. Malaysia: the South East Asian Central Banks (SEACEN) Research and Training Centre.

Maheshwari, Aditi, Alan Miller, and Shilpa Patel (2013). Mobilizing Public and Private Funds for Inclusive Green Growth Investment in Developing Countries: A Stocktaking Report Prepared for the G20 Development Working Group. Washington, D.C.: International Finance Corporation.

Multilateral Development Banks (MDBs) (2014). Joint Report on MDB Climate Finance 2013. Available from www.eib.org/projects/documents/joint-report-on-mdb-climate-finance-2013.htm.

Nakhooda, S., and others (2014), Climate Finance: Is It Making a Difference? A Review of the Effectiveness of Multilateral Climate Funds. London: Overseas Development Institute. Available from www.odi.org/sites/odi.org.uk/files/odi-assets/publications-opinion-files/ 9359.pdf.

Nepal, National Planning Commission (2011). Nepal Climate Public Expenditure and Institutional Review (CPEIR). Kathmandu. Available from http://climatefinance-development effectiveness.org/sites/default/files/documents/03_02_15/Nepal_CPEIR_Report_2011.pdf.

Norman, Marigold, and others (2014). Climate finance thematic briefing: REDD+ finance. Climate Finance Fundamentals, No. 5 (December). London: Overseas Development Institute. Available from www.odi.org/sites/odi.org.uk/files/odi-assets/publications-opinion-files/ 9330.pdf.

(2015). Climate finance thematic briefing: REDD+ finance. Climate Finance Fundamentals, No. 5 (December). London: Overseas Development Institute. Available from hwww.odi.org/ sites/odi.org.uk/files/odi-assets/publications-opinion-files/10054.pdf.

Overseas Development Institute (ODI) (2012a). Cambodia Climate Public Expenditure and Institutional Review. Bangkok: UNDP Regional Centre for Asia-Pacific. Available from www.climate finance-developmenteffectiveness.org/sites/default/files/documents/25_02_58/Cambodia_ CPEIR.pdf.

(2012b). Samoa Climate Public Expenditure and Institutional Review. Bangkok: UNDP Regional Centre for Asia-Pacific. Available from www.climatefinance-development effectiveness.org/sites/default/files/documents/03_02_15/cpeir\%20samoa\%20 content_ for\%20web.pdf.

(2012c). Thailand. Climate Public Expenditure and Institutional Review. Available from www.climatefinance-developmenteffectiveness.org/sites/default/files/documents/ 03_02_15/thailand\%20cpeir\%20report_final_24\%20june.pdf. 
Schalatek, Liane, and others (2012). Climate finance thematic briefing: adaptation finance. Climate Finance Fundamentals, No. 3 (November). London: Overseas Development Institute. Available from www.odi.org/sites/odi.org.uk/files/odi-assets/publications-opinion-files/ 7910.pdf.

United Nations, Economic and Social Commission for Asia and the Pacific (ESCAP) (2012a). Building Resilience to Natural Disasters and Major Economic Crises. Bangkok.

(2012b). Low Carbon Green Growth Roadmap for Asia and the Pacific - Turning Resource Constraints and the Climate Crisis into Economic Growth Opportunities. Bangkok. Available from www.unescap.org/sites/default/files/LGCC\%20summary\%20for\%20 policymakers\%202012.pdf.

(2013). Economic and Social Survey of Asia and the Pacific: Forward-looking Macroeconomic Policies for Inclusive and Sustainable Development. Sales No. E.13.II.F.2. Available from www.unescap.org/sites/default/files/Economic-and-Social-Survey-of-Asiaand-the-Pacific-2013_1.pdf.

(2014). Green banking policy: the role of financial sector actors. EDD Briefing Note, October. Bangkok.

United Nations Development Programme (UNDP) (2013). Global forum summary: using country systems to manage climate change finance. Paper prepared for the Global Forum on Climate Change Finance and Development Effectiveness. Incheon, Republic of Korea, 2-3 December. Available from www.oecd.org/dac/environment-development/Summary\%20 of $\% 20$ the $\% 20$ Global\%20Forum $\% 20$ on $\% 20$ Use $\% 20$ of $\% 20$ Country $\% 20$ Systems $\% 20$ to\%20Manage\%20Climate\%20Finance.pdf.

United Nations Environment Programme (UNEP) (2012). Finance. Green Economy Briefing Paper, June. Available from www.unep.org/greeneconomy/Portals/88/documents/GE_FINANCE\% 202juin.pdf.

United Nations Framework Convention on Climate Change (UNFCCC) (2007a). Decision 1/CP.13 Bali Action Plan. FCCC/CP/2007/6/Add.1. Available from http://unfccc.int/resource/docs/2007/ cop13/eng/06a01.pdf\#page=3.

(2007b). Investment and Financial Flows to Address Climate Change. Bonn. Available from https://unfccc.int/files/cooperation_and_support/financial_mechanism/application/pdf/ background_paper.pdf.

(2008). Investment and financial flows to address climate change: an update. FCCC/TP/ 2008/7. Available from unfccc.int/resource/docs/2008/tp/07.pdf.

(2014a). Focus: climate finance. Available from http://unfccc.int/focus/climate_finance/ items/7001.php\#intro. Accessed 3 November 2015.

(2014b). UNFCCC Standing Committee on Finance: 2014 Biennial Assessment and Overview of Climate Finance Flows Report. Bonn. Available from http://unfccc.int/files/ cooperation_and_support/financial_mechanism/standing_committee/application/pdf/ 2014_biennial_assessment_and_overview_of_climate_finance_flows_report_web.pdf.

United States Agency for International Development (USAID) (2013). Low Emissions Asian Development (LEAD) Program: Fast Out of the Gate - How Developing Asian Countries Can Prepare to Access International Green Growth Financing. Bangkok: USAID Regional Development Mission for Asia.

World Bank (2010). Climate Risks and Adaptation in Asian Coastal Megacities: A Synthesis Report Washington, D.C. 